\title{
Tmesiphantes hypogeus sp. nov. (Araneae, Theraphosidae), the first troglobitic tarantula from Brazil
}

\author{
ROGÉRIO BERTANI ${ }^{1}$, MARIA ELINA BICHUETTE ${ }^{2}$ and DENIS R. PEDROSO ${ }^{3}$ \\ ${ }^{1}$ Laboratório Especial de Ecologia e Evolução, Instituto Butantan, Av. Vital Brazil, 1500, 05503-900 São Paulo, SP, Brasil \\ ${ }^{2}$ Departamento de Ecologia e Biologia Evolutiva, Universidade Federal de São Carlos, \\ Rodovia Washington Luis, Km 235, 13565-905 São Carlos, SP, Brasil \\ ${ }^{3}$ Departamento de Invertebrados, Laboratório de Aracnologia, Museu Nacional, Universidade Federal do Rio de Janeiro, \\ Quinta da Boa Vista, s/n, São Cristóvão, 20940-040 Rio de Janeiro, RJ, Brasil
}

Manuscript received on December 5, 2011; accepted for publication on March 6, 2012

\begin{abstract}
A new species of Tmesiphantes Simon, 1892, is described from sandstone/quartizitic caves of Chapada Diamantina, Bahia State, Brazil. This is the fifth species of the genus and the first record of a troglobitic mygalomorph in Brazil. A key is presented for all Tmesiphantes species.
\end{abstract}

Key words: cave, mygalomorph, new species, spider taxonomy, tarantula.

\section{INTRODUCTION}

Theraphosid is the largest mygalomorph family, containing 937 of the 2,683 described mygalomorph species (Platnick 2011). Despite its high diversity and wide distribution throughout most tropical and subtropical areas in the world, a few troglobitic species are known (cave restricted organisms with autapomorphic character-states related to this isolation, mainly regression of eyes and body pigmentation - sensu Holsinger and Culver 1988). All of these species are included in a single genus, Hemirrhagus Simon, 1903, found exclusively in Mexico. Hemirrhagus has 16 species, and all species with published collection records were found inside caves, among which six are proven troglobites (Gertsch 1973, 1982, Pérez-Miles and

Correspondence to: Rogério Bertani

E-mail: rbert@butantan.gov.br /

rogerio.bertani@uol.com.br
Locht 2003, Redell 2005). Indeed, Hemirrhagus troglobitic species show high endemism, with each species restricted to a single cave.

Herein we describe a new species of theraphosid found in two Brazilian caves in the State of Bahia, representing the first theraphosid troglobites found in Brazil. The species is putatively included in the genus Tmesiphantes. This genus has 4 species: $T$. nubilus Simon, 1892, T. amadoi Yamamoto et al., 2007, T. bethaniae Yamamoto et al., 2007, and T. caymii Yamamoto et al., 2007, all found in the State of Bahia, Brazil.

\section{MATERIALS AND METHODS}

All measurements are presented in milimeters and were obtained with a Mitutoyo digital calliper with an error of $0.01 \mathrm{~mm}$. Leg and palp measurements were taken from the dorsal aspect of the left side (unless appendages were lost or obviously regenerated). 
A Nikon SMZ1500 dissecting microscope was used for illustrations (with a camera lucida attachment). Urticating hairs were examined and photographed with a Leica DM LB2 compound microscope. Urticating hair terminology follows Cooke et al. (1972), and leg spines terminology follows Petrunkevitch (1925) with modifications proposed by Bertani (2001).

Specimens are deposited in the Museu Nacional do Rio de Janeiro (MNRJ).

Abbreviations: ALE: anterior lateral eyes; AME: anterior median eyes; MNHN: Muséum national d'Histoire naturelle, Paris, France; PLE: posterior lateral eyes; PLS: posterior lateral spinnerets; PME: posterior median eyes; PMS: posterior median spinnerets; STC: superior tarsal claws.

\section{TAXONOMY}

\section{Tmesiphantes Simon, 1892}

Tmesiphantes Simon, 1892:277, type species Tmesiphantes nubilus Simon, 1892:277 by monotypy, syntypes 2 males and 2 females deposited in MNHN, examined; 1903:920, f.1078; Gerschman-dePikelin and Schiapelli 1973:76, f. 39-44; Pérez-Miles et al. 1996:59, f. 48; Yamamoto et al. 2007:972, f.2-8.

Diagnosis: See Pérez-Miles et al. (1996) and Yamamoto et al. (2007).

Species included: Tmesiphantes amadoi Yamamoto et al., 2007, Tmesiphantes bethaniae Yamamoto et al., 2007, Tmesiphantes caymmii Yamamoto et al., 2007, Tmesiphantes nubilus Simon, 1892, and Tmesiphantes hypogeus sp. nov.

\section{Identification key for Tmesiphantes.}

Males

(Male of T. hypogeus sp. nov. is unknown)

1. Palpal bulb with thick embolus having a strong curvature at the tip (Yamamoto et al. 2007: figs 3-5)...T. nubilus.

-Palpal bulb with slender embolus ...2
2. Palpal bulb embolus enlarged at the tip with a small serrulated keel (Yamamoto et al. 2007: figs 9 and 11)... T. amadoi

-Palpal bulb embolus with a slender tip lacking a small serrulated keel...3

3. Palpal bulb embolus with a serrated inferior prolateral keel extending along the embolus (Yamamoto et al. 2007: fig. 15... T. caymmii -Palpal bulb lacking a serrated prolateral keel...T. bethaniae

\section{Females}

(Females of $T$. amadoi and T. bethaniae are unknown)

1. AME strongly reduced, shorter than PME; eye tubercle low, mostly transparent; urticating hair region reduced to two dorso-lateral patches (Figs 1, 2A, 2C)...T. hypogeus sp. nov.

-AME larger than PME, eye tubercle opaque; urticating hair patch covers most of abdomen dorsally...2

2. Spermatheca receptacula dilated apically (Yamamoto et al. 2007: fig. 8)...T. nubilus -Spermathecae receptacula tapering distally (Yamamoto et al. 2007: fig. 19)...T. amadoi

\section{Tmesiphantes hypogeus sp. nov.}

Figures 1-5

Type material: Holotype: female: Brazil, Bahia, Andaraí, Igatu, Gruna da Parede Vermelha, $12^{\circ} 52^{\prime} 42.8^{\prime \prime} \mathrm{S} \quad 41^{\circ} 18^{\prime} 59.5^{\prime \prime} \mathrm{W}, 29$ October 2010, M.E. Bichuette and J.E. Gallão (MNRJ 04357).

Paratype: female: Brazil, Bahia, Andaraí, Igatu, Gruna das Cobras cave, $12^{\circ} 52^{\prime} 02.8^{\prime \prime S}$ 41 $18^{\prime} 11.9^{\prime \prime}$ W, 30 July 2010, J.E. Gallão and M.E. Bichuette (MNRJ 04419).

Other material examined: Only the types.

Diagnosis: Females can be distinguished from all Tmesiphantes species by highly reduced AME that is shorter than PME, mostly transparent eye 


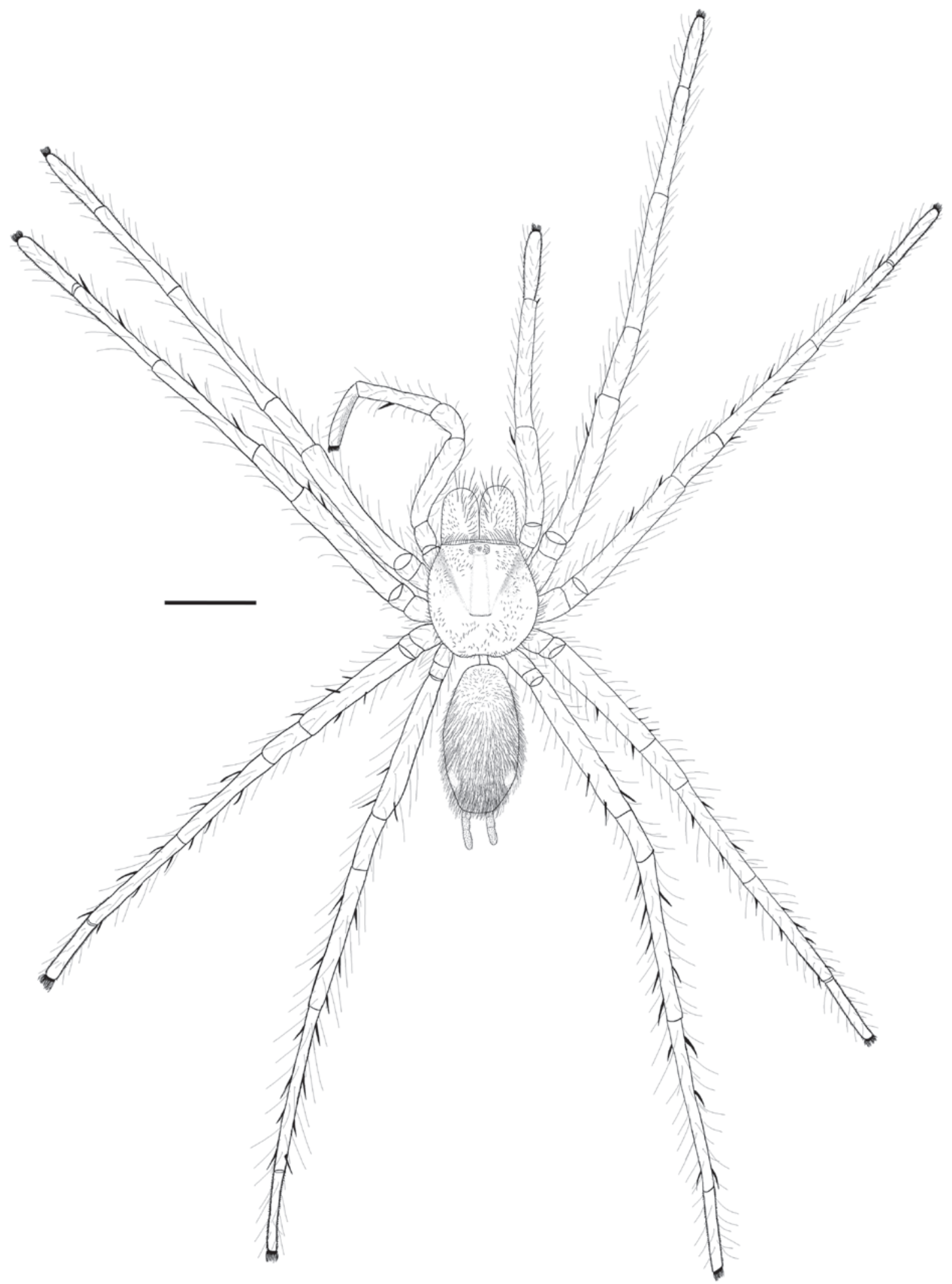

Fig. 1 - Tmesiphantes hypogeus sp. nov. Holotype female, habitus. Scale bar: $5 \mathrm{~mm}$. 
tubercle (Figs 2A, 2C), slender legs (Fig. 1) and reduction of the urticating hair area to two small patches on dorso-lateral abdomen (Figs 1, 2A).

Etymology: The specific name is from the Latin adjective (masculine) hypogeus (underground), referring to the isolated site condition.

Description: Female (holotype, Figs 1, 2A-D, 3, 4). Carapace 6.01 long, 5.61 wide, chelicerae 2.90. Legs (femur, patella, tibia, metatarsus, tarsus, total): I: 7.39, 2.92, 7.56, 5.55, 3.97, 27.39. II: 7.16, 3.10, 7.04, 5.74, 3.70, 26.74. III: 6.72 , 2.62, 6.12, 6.29, 3.67, 25.42. IV: 7.99, 2.93, 8.50, 8.75, 4.17, 32.34. Palp: 5.10, 2.54, 4.32, -, 3.48, 15.44. Midwidths: femora I-IV $=1.10,0.97,1.08$, 1.04, palp=1.01; patellae $\mathrm{I}-\mathrm{IV}=1.02,0.97,1.02$, 1.04, palp $=1.09$; tibiae $\mathrm{I}-\mathrm{IV}=0.74,0.75,0.76$, 0.79 , palp $=0.81$; metatarsi $\mathrm{I}-\mathrm{IV}=0.61,0.61,0.58$, 0.57 ; tarsi $\mathrm{I}-\mathrm{IV}=0.62,0.61,0.59,0.57$, palp $=0.71$. Abdomen 7.24 long, 3.86 wide. Spinnerets: PMS, 0.69 long, 0.21 wide, 0.30 apart; PLS, 1.37 basal, 0.92 middle, 1.18 distal; midwidths $0.41,0.41$, 0.34 , respectively.

Carapace: Length to width 1.07 ; cephalic area raised, thoracic striae narrow. Fovea: deep, straight, 1.33 wide. Carapace with short, thick, sparse setae; bordered with setae pointing out.

Eyes and eye tubercle: Tubercle 0.01 high, length 0.71 , width 1.20. Clypeus 0.24. Anterior row procurved, posterior slightly recurved (Figs 2A, 2C). Sizes and inter-distances: AME 0.12, ALE 0.38, PME 0.19, PLE 0.26, AME-AME 0.14, AME-ALE 0.19, AME-PME 0.08, ALE-ALE 0.61, ALE-PME 0.16, PME-PME 0.37, PME-PLE 0.08, PLE-PLE 0.81, ALE-PLE 0.04, AME- PLE 0.32 . Eye group width to length 2.36 .

Maxillae: Length to width: 1.38. Cuspules: ca. 100 spread over ventral inner heel (Fig. 2B). Lyra absent. Labium: Length 0.92, width 1.46, with 18 cuspules. Labio-sternal groove deep, flat, without sigilla (Fig. 2B). Chelicerae: Rastellum absent, basal segments with 9 and 10 teeth on promargin, on the left and right chelicera, respectively. Sternum: Length 2.57, width 2.87. Posterior angle rounded, not separating coxae IV. Sigilla: Three pairs, posterior elongated, others rounded, one diameter from margin (Fig. 2B).

Legs: Formulla: IV I II III. Clavate trichobothria: On central 2/4 of tarsi I-IV. Leg coxae: With sparse stiff short setae; stridulatory or modified setae lacking. Scopula sparce: Tarsi I-II with a double line of sparse setae; III-IV divided by three wide rows of setae. Metatarsi I-II 1/3 scopulated; III 1/5, IV ascopulate. Femur IV lacks retrolateral scopula. Spines: palp: femur p0-0-2ap, patella 0, tibia v24-3ap, p0-1-0; leg I: femur p0-0-1ap, patella 0, tibia v0-3-2ap, p0-1-0, metatarsus v2-2-2ap; leg II: femur p0-2-2(1ap), patella 0, tibia v1-3-2ap, p0-10; metatarsus v2-3-3ap, p0-1-1ap; leg III: femur p0-2-1, r0-1-1, patella 0, tibia v2-3-2ap, p1-1-0, r1-1-0, metatarsus v3-3-4(3ap), p1-1-1ap, r1-1lap; leg IV: femur p0-1-1, r0-1-1, patella 0, tibia v2-3-2ap, p1-1-0, r1-1-1, metatarsus v3-3-5(3ap), p1-1-1, r1-1-2. Claws: ITC absent from all legs; STC without teeth.

Urticating hairs: Two small oval areas on posterior dorso-lateral abdomen (Fig. 2A) having type III hairs $0.32 \mathrm{~mm}$ in length (Fig. 3).

Genitalia (Fig. 2D): Two short, almost triangular in shape, widely separated spermathecae.

Color (in alcohol): Carapace, chelicerae, legs, labium and sternum light yellowish brown. Abdomen light brown with longer greiysh hairs.

Variation (paratype): Carapace 6.86 long, 6.15 wide, chelicerae 3.80. Legs (femur, patella, tibia, metatarsus, tarsus, total): I: 7.47, 3.56, 7.97, 5.79, 3.90, 28.69. II: 7.40, 3.14, 6.23, 5.97, 3.74, 26.48 . III: 6.81, 2.82, 6.21, 6.66, 3.62, 26.12. Leg IV missing on both sides. Palp: 5.15, 2.82, 4.72,-, 3.60, 16.29. Midwidths: femora $\mathrm{I}-\mathrm{III}=1.14,1.04$, 1.23, palp=1.06; patellae I-III=1.01, 1.09, 1.08, 

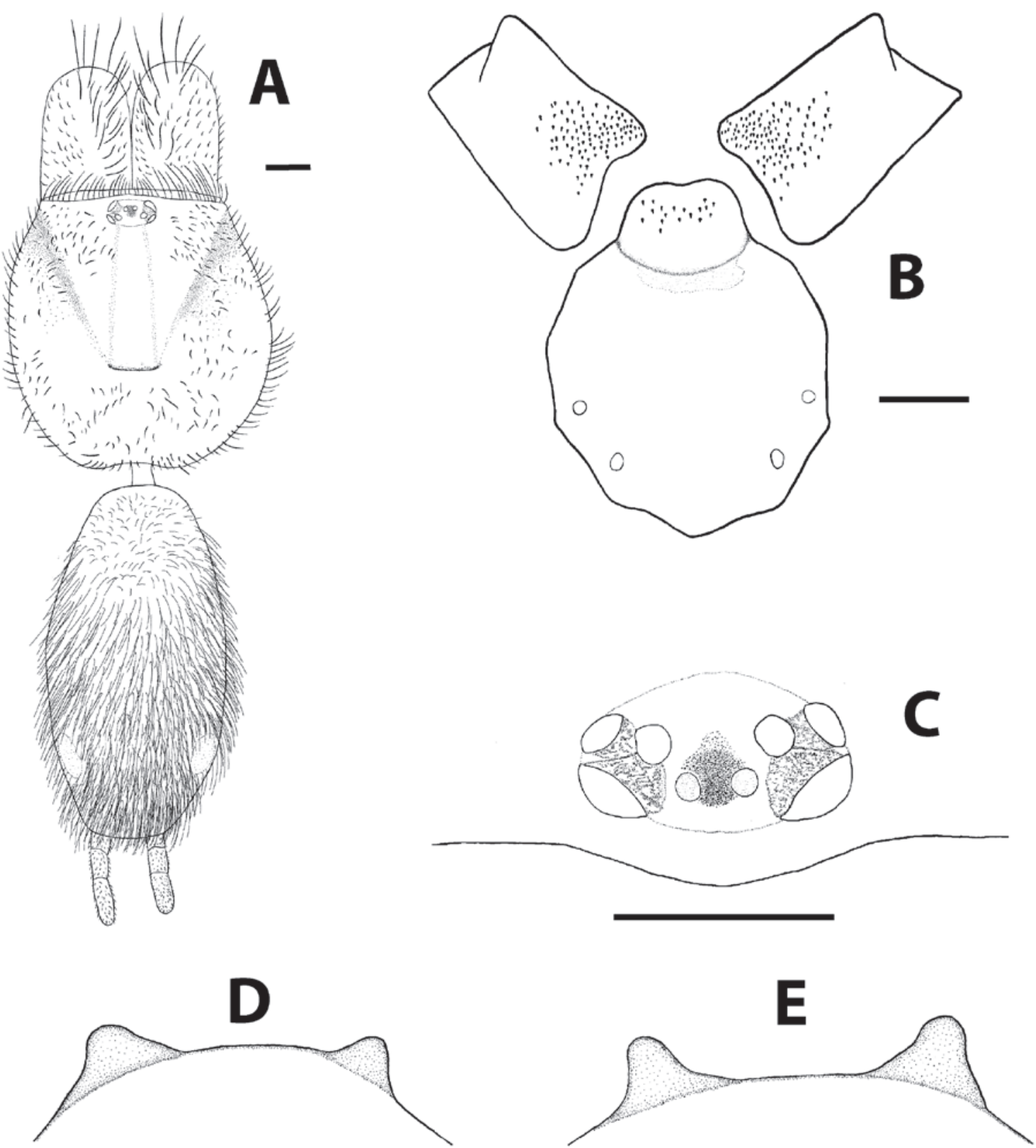

Fig 2 - Tmesiphantes hypogeus sp. nov. A-D Holotype female; A, Cephalothorax and abdome, dorsal; B, Sternum, labium and maxillae; C, Eye tubercle; D-E, Spermathecae, dorsal; D, Holotype; E, Paratype. Scale bars: $1 \mathrm{~mm}$.

palp $=1.10$; tibiae $\mathrm{I}-\mathrm{III}=0.82,0.78,0.81$, palp $=0.79$; metatarsi $\mathrm{I}-\mathrm{III}=0.61,0.64,0.75$; tarsi $\mathrm{I}-\mathrm{III}=0.63$, 0.60, 0.45, palp $=0.66$. Abdomen 8.08 long, 4.02 wide. Spinnerets: PMS, 0.74 long, 0.29 wide, 0.33 apart; PLS missing on both sides.
Carapace: Length to width 1.11; Fovea: 1.28 wide. Eyes and eye tubercle: Tubercle 0.01 high, length 0.76 , width 1.08. Clypeus 0.18. Anterior row procurved, posterior slightly recurved. Sizes and inter-distances: AME 0.10, ALE 0.39, PME 0.14, 


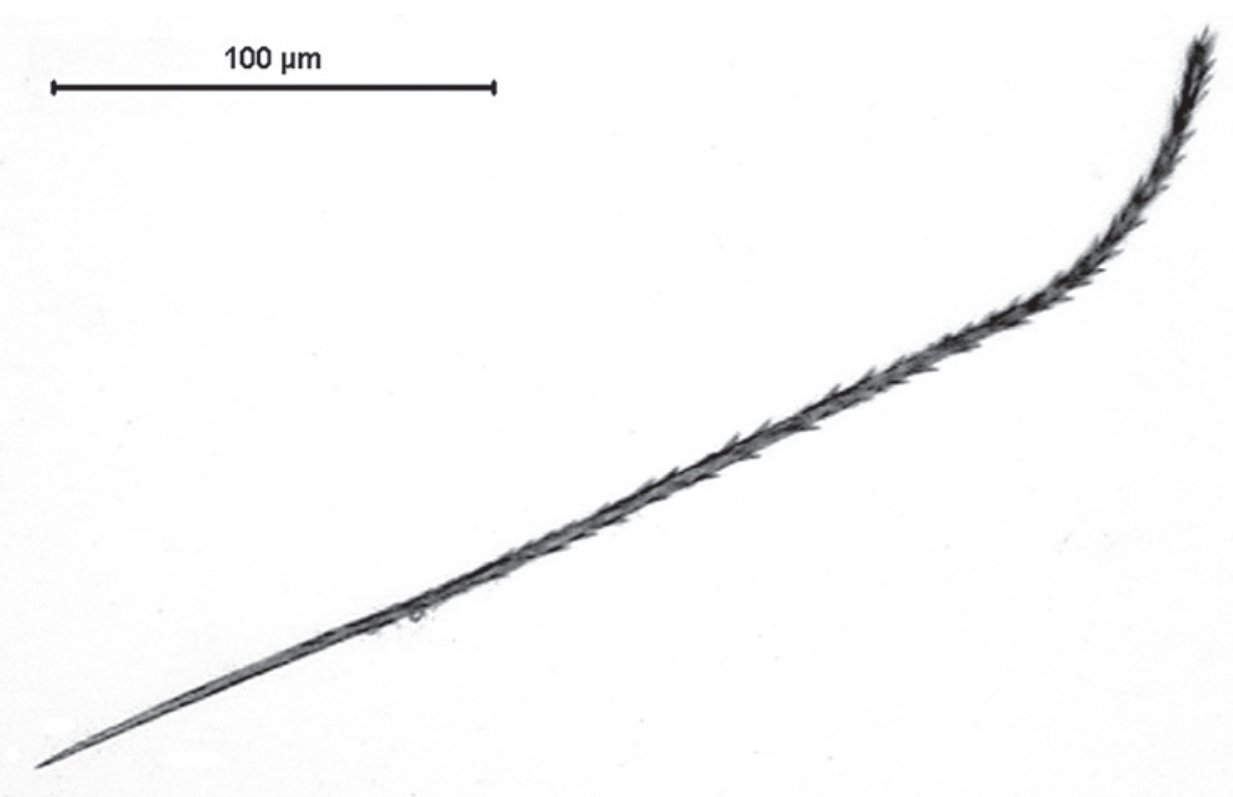

Fig. 3 - Tmesiphantes hypogeus sp. nov. Holotype female. Type III urticating hair.

PLE 0.24, AME-AME 0.13, AME-ALE 0.16, AME-PME 0.09, ALE-ALE 0.53, ALE-PME 0.14, PME-PME 0.38, PME-PLE 0.04, PLE-PLE 0.73, ALE-PLE 0.04, AME-PLE 0.31. Eye group width to length 1.99 .

Maxillae: Length to width: 1.27. Cuspules: ca. 100 spread over ventral inner heel. Labium: length 1.07, width 1.44, with 9 cuspules. Labio-sternal groove with two large sigillae. Chelicerae: Basal segments with 8 and 9 teeth on promargin, on the left and right chelicera, respectively. Sternum: length 2.87, width 3.08. Scopula sparce: Tarsi I-II with a double line of setae. Spines: palp: femur p0-0-2, patella 0 , tibia v2-4-3ap; leg I: femur p0-1-1, patella 0 , tibia v1-3-1ap, metatarsus v1-3-2ap; leg II: femur p01-1, patella 0 , tibia v1-3-2ap, p1-1-0; metatarsus v3-4-3ap, p0-1-1ap; leg III: femur p1-1-1, r0-1-1, patella 0 , tibia v2-4-2ap, p1-1-1, r1-1-1, metatarsus v5-4-2ap, p2-1-1ap, r1-1-1ap. Claws: STC with a row of denticles.

Urticating hairs: absent, abdomen completely bald.

Genitalia (Fig. 2E) and color: Same as the holotype.

\section{DISCUSSION}

Tmesiphantes hypogeus sp. nov. has a reduced anterior median eye that is even smaller than its posterior median eye, a characteristic uncommon in theraphosids (Fig. 2C) that could be considered a troglomorphic character. The eye tubercle is low and mostly transparent, allowing one to see the internal structures of the anterior lateral eye, posterior median eye, and posterior lateral eye (Fig. 2C). Pigmentation circumscribes central eye tubercle area (Fig. 2C). Legs are long and slender (Fig. 1) and quite lacking in pigment (Fig. 4), another troglomorphic character possibly related to isolation in cave habitats. Urticating hairs (Fig. 3) are present only in two small postero-lateral dorsal patches (Figs 1, 2A). All of these characteristics are shared with species of Hemirrhagus, the only theraphosid genus containing troglobitic species, and are considered evidence for a troglobitic lifestyle (Gertsch 1973, 1982, Pérez-Miles and Locht 2003). On the other hand, Tmesiphantes hypogeus sp. nov. lacks two proposed synapomorphies of Hemirrhagus: ventral coxae with retrolateral 


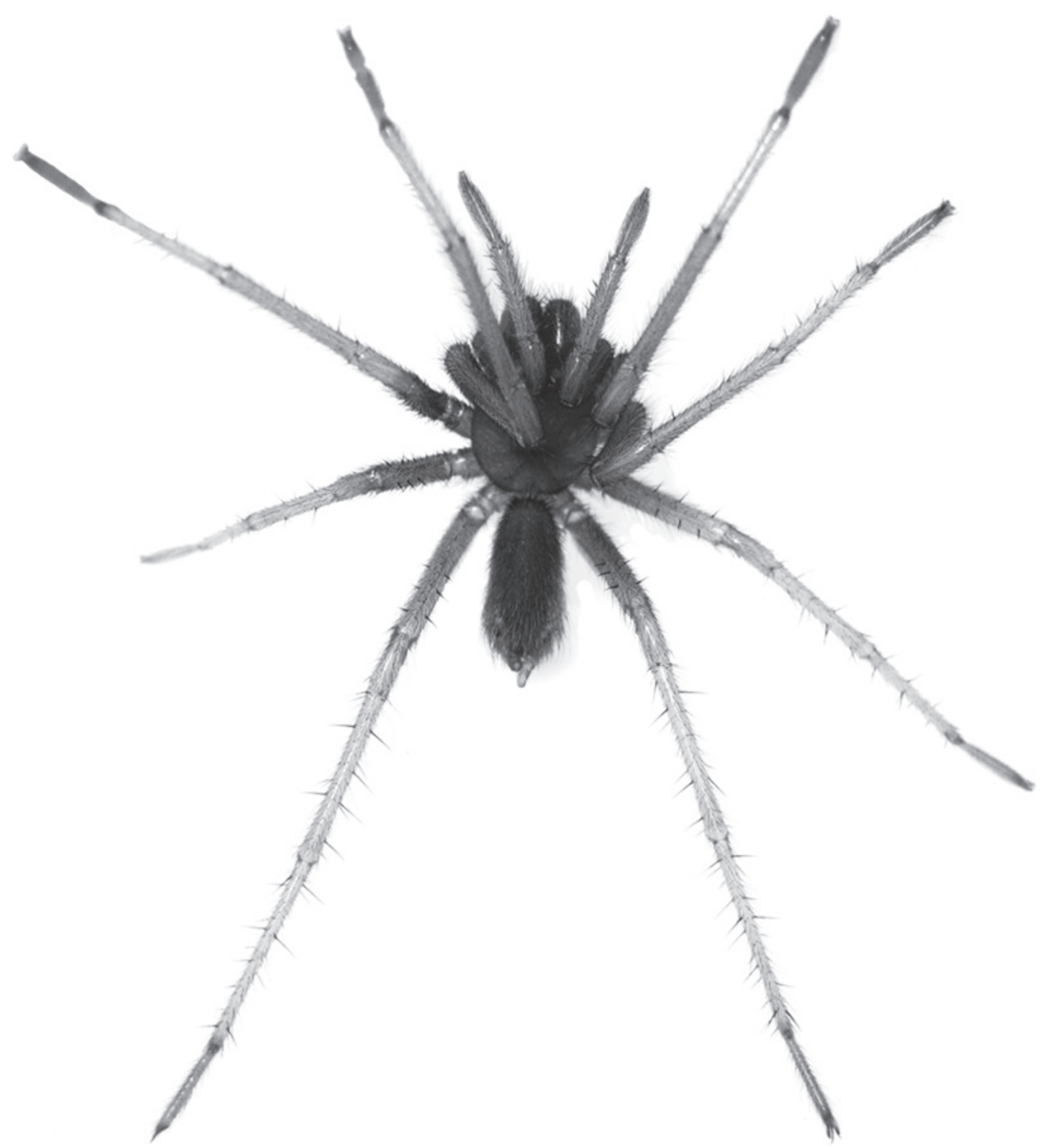

Fig. 4 - Tmesiphantes hypogeus sp. nov. Holotype female. Photo: M. E. Bichuette.

projection and type VI urticating hair on the abdomen dorsum (Pérez-Miles 1998, Pérez-Miles and Locht 2003). Therefore, we consider the shared characteristics to be morphological convergences due to their similar habitat use, and we include the new species putatively in the genus Tmesiphantes because of the almost circular sternum (Fig. 2B), low number of labial cuspules (Fig. 2B), presence of type III urticating hair (Fig. 3) and widely separated spermathecae that taper to their apex (Figs 2D,
2E). Furthermore, all four described Tmesiphantes species are found also in State of Bahia. A more precise classification of the species would be possible only if a male were collected; however, due to the rarity of the species this is not expected to occur soon. Due to the absence of Tmesiphantes hypogeus sp. nov. from epigean environments in Chapada Diamantina as well as the presence of troglomorphic characteristics, we deduce that this species is categorically a troglobitic species, 


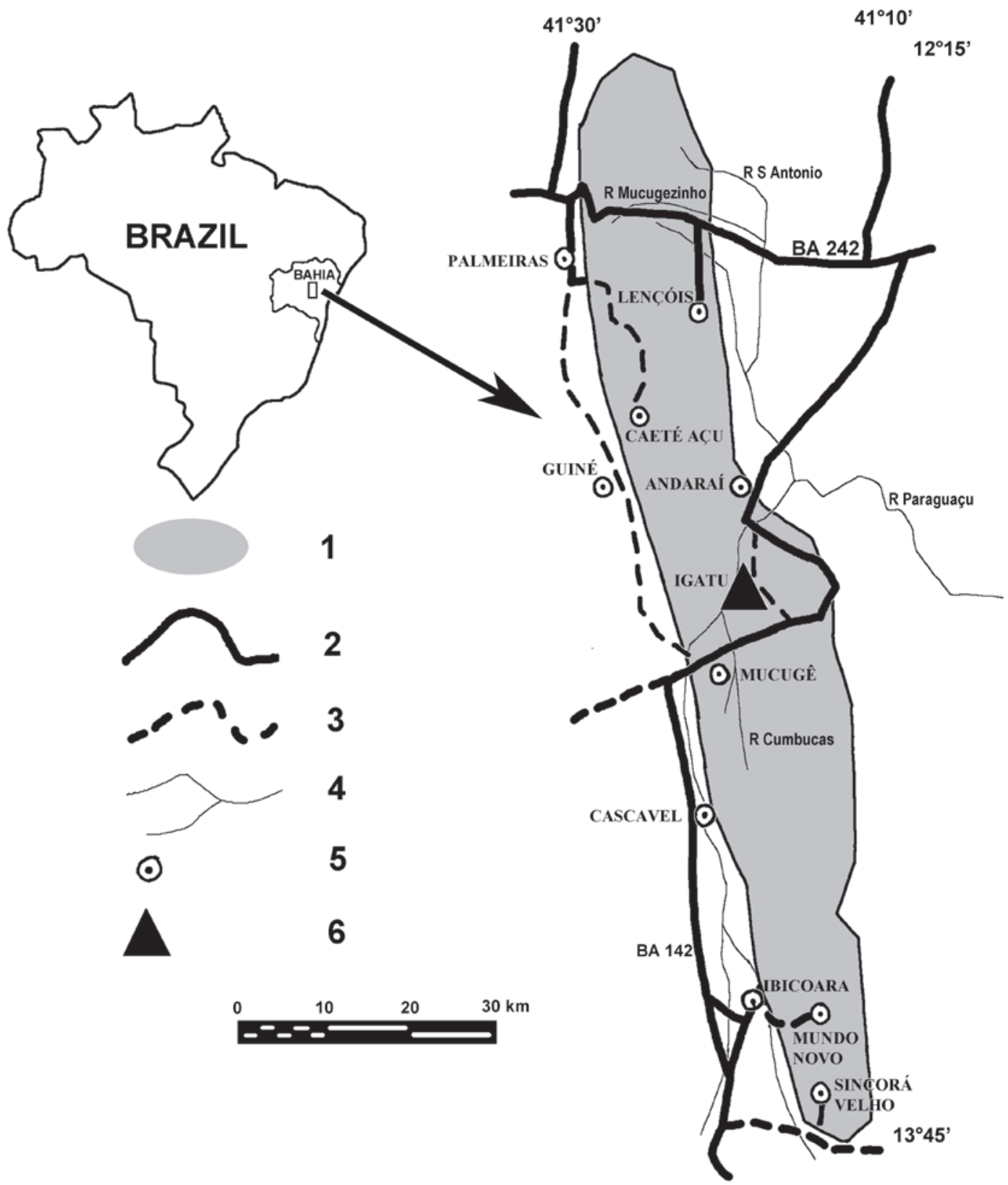

Fig. 5 - Type locality of Tmesiphantes hypogeus sp. nov. In detail - Chapada Diamantina National Park, Central Bahia, northeastern Brazil: 1, Boundaries of National Park; 2, Federal Roads; 3, Secondary Roads; 4, Rivers; 5, Cities; 6, Povoado de Igatu, collection area of the new mygalomorph.

indicating a process of differentiation occurring in isolation in the hypogean environment.

Distribution: Two sandstone/quartzitic caves in Povoado de Igatu, Andaraí county, Central Bahia, northeastern Brazil: Gruna das Cobras and Gruna da Parede Vermelha (Fig. 5).
Habitat description: The localities where Tmesiphantes hypogeus sp. nov. were found are sandstone/quartzitic caves $0.8 \mathrm{~km}$ distant from each other. The area is in the Espinhaço mountains (Fig. 5), and the region is composed of metasedimentary rocks deposited over a 
billion years ago (Proterozoic era) formed mainly by sandstone, siltites and argilites. This spider shows a preference for rocky and humid substrates typical of parietal species. Both specimens were recorded exposed in the rocks, not showing cryptobiotic habits, as is typical of Mygalomorphae species, so there is strong evidence of regression in this behavior.

\section{ACKNOWLEDGMENTS}

We are grateful to several colleagues who helped in the field and laboratory, especially to Jonas E. Gallão, who called our attention to the discovery. We also thank Raimundo C. dos Santos ("Xiquinho") and Rafael P. de Souza, our guides in Igatu, Bianca Rantin for helping in the fieldwork, and Rute M. G. Andrade for the microphotographs. We thank Cristine Rollard (MNHN) for the loan of Tmesiphantes nubilus types. Thanks also to the environmental governmental agency ICMBIO (Instituto Chico Mendes de Biodiversidade) for the collection permission (license number 20165-1). This work was financially supported by the Fundação de Amparo à Pesquisa no Estado de São Paulo (FAPESP, process number 2008/05678-7). Conselho Nacional de Desenvolvimento Científico e Tecnológico (CNPq) Research Fellow - Brazil for RB.

\section{RESUMO}

Uma nova espécie de Tmesiphantes Simon, 1892, é descrita em cavernas areníticas/quatzíticas da Chapada Diamantina, estado da Bahia, Brasil. Essa é a quinta espécie do gênero e o primeiro registro de uma migalomorfa troglóbia do Brasil. É apresentada chave de identificação para todas as espécies de Tmesiphantes.

Palavras-chave: caverna, migalomorfa, espécie nova, taxonomia de aranhas, tarantula.

\section{REFERENCES}

BERTANI R. 2001. Revision, cladistic analysis, and zoogeography of Vitalius, Nhandu, and Proshapalopus; with notes on other theraphosine genera (Araneae, Theraphosidae). Arq Zool 36: 265-356.

CoOKe JAL, Roth VD AND Miller FH. 1972. The urticating hairs of theraphosid spiders. Amer Mus Novitates 2498: $1-43$.

GERSCHMAN-DE-PIKELIN BS AND SCHIAPELLI RD. 1973. La subfamilia Ischnocolinae (Araneae: Theraphosidae). Rev Mus Argentino Cienc Nat Ent 4: 43-77.

GERTSCH WJ. 1973. A report on cave spiders from Mexico and Central America. Assoc Mex Cave Stud Bull 5: 141-163.

GERTSCH WJ. 1982. The troglobitic mygalomorphs of the Americas (Arachnida, Araneae). Assoc Mex Cave Stud Bull 8: 79-94.

Holsinger JR AND CULVER DC. 1988. The invertebrate cave fauna of Virginia and a part of Eastern Tennessee: Zoogeography and ecology. Brimleyana 14: 1-162.

PÉREZ-Miles F. 1998. Notes on the Systematics of the Little Known Theraphosid Spider Hemirrhagus cervinus, With a Description of a New Type of Urticating Hair. J Arachnol 26: 120-123.

PÉREZ-Miles F AND LOCHT A. 2003. Revision and cladistic analysis of the genus Hemirrhagus Simon, 1903 (Araneae, Theraphosidae, Theraphosinae). Bul British Arachnol Soc 12: 365-375.

PÉREZ-Miles F, LuCAS SM, SILVA JunIOR PI AND BERTANI R. 1996. Systematic revision and cladistic analysis of Theraphosinae (Araneae: Theraphosidae). Mygalomorph 1: 33-68.

Petrunkevitch A. 1925. Arachnida from Panamá. Trans Connecticut Acad Arts Sci 27: 51-248.

PlatNICK NI. 2011. The world spider catalog, version 12.0. American Museum of Natural History, online at http:// research.amnh.org/iz/spiders/catalog. DOI: 10.5531/db.iz. 0001. [accessed 10.XI.2011].

REDELL JR. 2005. Spiders and related groups. In: Culver DC and White WB (Eds), Encyclopedia of Caves, Amsterda: Academic Press, Amsterda, The Netherlands, p. 554-564.

SIMON E. 1892. Etudes arachnologiques. 24e Mémoire. XXXIX. Descriptions d'espèces et de genres nouveaux de la famille des Aviculariidae (suite). Ann Soc Ent France 61: 271-284.

SIMON E. 1903. Histoire naturelle des araignées. Paris 2: 669-1080.

YAMAMOTO FY, LUCAS SM, GUADANUCCI JPL AND INDICATTI RP. 2007. Revision of the genus Tmesiphantes Simon (Araneae, Mygalomorphae, Theraphosidae). Rev Bras Zool 24: 971-980. 